\title{
Holothuria scabra Memperbaiki Fibrosis Hepar pada Tikus yang Diinduksi Karbon Tetraklorida
}

\author{
Holothuria scabra Improves Carbon Tetrachloride-Induced Liver Fibrosis in Rats
}

\author{
Novrita Padauleng ${ }^{1}$, Nurhidayati ${ }^{2}$ \\ ${ }^{1}$ Bagian Histologi Fakultas Kedokteran Universitas Mataram Mataram \\ ${ }^{2}$ Bagian Farmakologi Fakultas Kedokteran Universitas Mataram Mataram
}

\begin{abstract}
ABSTRAK
Perkembangan agen antifibrotik belakangan ini mencakup berbagai mekanisme, diantaranya melalui jalur antioksidan. Salah satu bahan alam yang diketahui memiliki aktivitas antioksidan adalah Teripang pasir (Holothuria scabra). Tujuan penelitian ini adalah menganalisa aktivitas antifibrotik Teripang pasir in vivo menggunakan tikus fibrosis hepar yang diinduksi CCl4. Dua puluh delapan tikus Wistar jantan dibagi menjadi 4 kelompok penelitian, yang terdiri dari kelompok kontrol vehicle (injeksi minyak zaitun intraperitoneal), kelompok kontrol induksi CCl4 (injeksi CCl4 dalam minyak zaitun intraperitoneal), serta dua kelompok perlakuan (tikus diinduksi CCl4 dan diberikan Teripang pasir 75 dan 100mg/200gBB). Fibrosis hepar diinduksi dengan injeksi CCl4 10\% dalam minyak zaitun serial selama 5 minggu, diikuti 4 minggu pemberian Teripang pasir peroral (75 dan 100mg/200gBB) sekali sehari, sejak minggu ke-5. Fibrosis hepar dianalisa menggunakan sistem scoring METAVIR pada jaringan dengan pewarnaan Mallory. Hasil penelitian menunjukkan bahwa derajat fibrosis hepar pada kelompok kontrol induksi CCl4 berbeda signifikan dengan kelompok perlakuan yang diinduksi $\mathrm{CCl} 4$ dan diberikan Teripang pasir $(p=0,000)$, namun perbedaan antara kelompok perlakuan yang diberikan Teripang pasir 75 dan $100 \mathrm{mg} / 200 \mathrm{gBB}$ tidak signifikan $(p=0,081)$. Sebagai kesimpulan, pemberian ekstrak Teripang pasir dapat memperbaiki fibrosis hepar yang diinduksi CCl4.
\end{abstract}

Kata Kunci: $\mathrm{CCl} 4$, fibrosis hepar, teripang pasir (Holothuria scabra)

\begin{abstract}
Recently, the development of antifibrotic agents has covered a variety of mechanisms, including through antioxidant pathway. One of the natural compounds known to have antioxidant activity is Sandfish (Holothuria scabra). The aim of this study is to analyze the antifibrotic activity of Sandfish in vivo on CCl4-induced liver fibrosis in rats. Twenty eight male Wistar rats were divided into 4 experimental groups consisting of vehicle control (intraperitoneal injection of olive oil), CCl4induced control (intraperitoneal injection of CCl4 in olive oil), and two treatment groups (CCl4-induced rats with the administration of 75 and $100 \mathrm{mg} / 200 \mathrm{gBW}$ of Sandfish). Liver fibrosis were induced by serial injection of $10 \%$ CCl4 in olive oil for 5 weeks, followed by 4 weeks of oral administration of Sandfish ( 75 and $100 \mathrm{mg} / 200 \mathrm{gBW}$ ) once daily, began at $5^{\text {th }}$ week. Liver fibrosis were analyzed using METAVIR scoring system in a Mallory-stained sections. The results show that the stage of liver fibrosis in CCl4-induced control group was significantly different with treatment groups which were induced by CCl4 and administered with Sandfish $(p=0,000)$, but the difference between treatment groups administered with 75 and 100 $\mathrm{mg} / 200 \mathrm{gBW}$ of Sandfish ( $p=0,081)$ was insignificant. In conclusion, administration of Sandfish is able to improve the CCl4induced liver fibrosis.
\end{abstract}

Keywords: CCI4, liver fibrosis, sandfish (Holothuria scabra)

Korespondensi: Novrita Padauleng. Fakultas Kedokteran, Universitas Mataram, Jl. Pendidikan No. 37, Mataram,83125, Nusa Tenggara Barat Tel. (0370)640874 Email:novrita9888@yahoo.com 


\section{PENDAHULUAN}

Fibrosis hepar merupakan salah satu karakteristik penyakit hepar kronis yang paling sering terjadi. Kelainan ini disebabkan oleh kerusakan kronis pada organ hepar yang ditandai dengan akumulasi protein matriks ekstraseluler. Penyebab fibrosis hepar antara lain infeksi virus hepatitis kronis (HCV \& HBV), penyalahgunaan alkohol, obat dan toksin, serta non-alcoholic steatohepatitis (NASH) (1-5). Tingginya kasus hepatitis di Indonesia menjadi salah satu alasan pentingnya upaya identifikasi dan pengembangan terapi antifibrotik.

Agen antifibrotik yang sedang berkembang saat ini meliputi berbagai jalur mekanisme. Diantaranya inhibisi aktivasi dan fungsi hepatic stellate cells (HSCs), inhibisi respon inflamasi, inhibisi stres oksidatif, serta antioksidan (6-8). Terapi antioksidan terbukti bersifat efektif menghambat atau mengurangi kerusakan fibrosis hepar. Salah satu bahan dari alam yang diduga mengandung bahan aktif antioksidan adalah teripang. Teripang kaya akan kandungan zat gizi, diantaranya vitamin $A, C$ dan $E$, senyawa polifenol dan flavonoid, kondroitin sulfat, asam lemak eikosapentanoat (EPA) serta dokosaheksanoat (DHA) yang bersifat antioksidan dan antiinflamasi (9-15).

Indonesia merupakan penghasil teripang terbesar di dunia, setidaknya terdapat 26 spesies teripang. Salah satu jenis teripang yang banyak terdapat di Provinsi Nusa Tenggara Barat adalah teripang pasir (Holothuria scabra). Senyawa yang terkandung dalam teripang diduga juga terkandung dalam teripang pasir, dengan demikian teripang pasir diharapkan mampu menghambat fibrosis hepar melalui jalur antioksidan. Penelitian sebelumnya oleh Nurhidayati (2009), membuktikan bahwa simplisia teripang pasir dosis $50 \mathrm{mg} / 200 \mathrm{gBB}$ tikus, memiliki efek proteksi terhadap hepatotoksisitas yang diinduksi kabon tetraklorida (CCl4) dosis tunggal (16).

Penelitian ini bertujuan untuk menganalisa aktivitas antifibrotik Teripang pasir in vivo menggunakan tikus fibrosis hepar yang diinduksi $\mathrm{CCl} 4$. Hasil penelitian ini diharapkan mendukung upaya penemuan obat baru khususnya untuk fibrosis hepar.

\section{METODE}

Teripang pasir yang digunakan pada penelitian ini adalah teripang pasir (Holothuria scabra) dewasa, berukuran $15 \mathrm{~cm} \times 6 \mathrm{~cm}$, dan berat 2000 gram, yang berasal dari perairan Bima, Nusa Tenggara Barat. Simplisia teripang pasir dibuat ekstrak dengan metode maserasi. Simplisia teripang pasir dosis 75 dan $100 \mathrm{mg} / 200 \mathrm{gBB}$ dikonversi menjadi ekstrak dosis 11,25 dan 15mg/200gBB (1mg simplisia setara dengan $0,15 \mathrm{mg}$ ekstrak).

Uji potensi teripang pasir terhadap fibrosis hepar in vivo pada penelitian ini menggunakan 28 ekor tikus putih (Rattus norvegicus), strain Wistar, jenis kelamin jantan, umur 3-4 bulan dengan berat badan antara 200-250 gram. Jumlah sampel ditentukan berdasarkan rumus Federer dengan faktor koreksi $15 \%$. Subyek dibagi dengan metode randomisasi sederhana menjadi empat kelompok, yaitu kelompok kontrol vehicle (injeksi minyak zaitun intraperitoneal), kontrol induksi CCl4 (injeksi CCl4 10\% dalam minyak zaitun), perlakuan 1 (diinduksi CCl4 10\% dan diberikan teripang pasir $75 \mathrm{mg} / 200 \mathrm{gBB}$ ), dan perlakuan 2 (diinduksi CCl4 10\% dan diberikan teripang pasir 100mg/200gBB).
Induksi fibrosis hepar dilakukan dengan injeksi $1 \mathrm{ml} / \mathrm{kgBB}$ senyawa $\mathrm{CCl} 410 \%$ dalam pelarut minyak zaitun, intraperitoneal, 3 kali dalam seminggu selama 5 minggu (17). Selanjutnya tikus kelompok perlakuan diberikan teripang pasir sebanyak $75 \mathrm{mg} / 200 \mathrm{gBB}$ dan $100 \mathrm{mg} / 200 \mathrm{gBB}$ dalam pelarut CMC $1 \%$ (carboxymethyl cellulose), dengan volume $1 \mathrm{cc} / 10 \mathrm{mg}$ secara peroral menggunakan sonde, 1 kali sehari, selama 4 minggu sejak minggu ke-5. Misal berat tikus 350g, maka dosis ekstrak teripang pasir yang diberikan pada tikus kelompok perlakuan 1 adalah sebanyak $19,7 \mathrm{mg}$ (350g x $11,25 \mathrm{mg} / 200 \mathrm{~g}$ ) dalam $1,9 \mathrm{ml}$ pelarut CMC $1 \%$. Sementara untuk berat tikus yang sama pada kelompok perlakuan 2 diberikan ekstrak teripang pasir sebanyak 26,2 mg (350g x $15 \mathrm{mg} / 200 \mathrm{~g}$ ) dalam 2,6 ml pelarut CMC $1 \%$.

Tikus dikurbankan pada akhir minggu ke-8 penelitian untuk dinilai gambaran histopatologi fibrosis hepar tikus menggunakan sistem scoring METAVIR. Sistem ini menilai derajat fibrosis berdasarkan skala 1-4, terdiri dari F0 (tidak fibrosis atau tidak terdapat pembesaran traktus portal serta septa), F1 (Fibrosis portal tanpa septa), F2 (Fibrosis portal, dengan sedikit septa atau jaringan fibrosa disekitar traktus portal), F3 (Fibrosis portal dengan banyak septa atau jaringan fibrosa yang menghubungkan traktus portal dengan traktus portal atau dengan vena sentralis atau bridging fibrosis), dan F4 (sirosis) (18). Pengamatan derajat fibrosis dilakukan pada dua irisan jaringan hepar dengan ketebalan $5 \mu \mathrm{m}$ yang diberi pewarnaan khusus Trichrome mallory dan diamati dengan mikroskop perbesaran total $100 \mathrm{X}$ dan $400 \mathrm{X}$, di 5 lapang pandang. Analisa statistik data skor fibrosis dilakukan dengan uji Kruskal-Wallis yang dilanjutkan uji post hoc Mann-Whitney, dengan tingkat kemaknaan uji sebesar 0,05.

\section{HASIL}

Perbandingan mean skor derajat fibrosis pada keempat kelompok penelitian menunjukkan bahwa terdapat perbedaan yang signifikan $(p=0,000)$ (Tabel 1$)$.

Tabel 1. Perbandingan frekuensi derajat fibrosis pada kelompok penelitian

\begin{tabular}{lcc}
\hline \multicolumn{1}{c}{ Kelompok penelitian } & $\begin{array}{c}\text { Skor derajat } \\
\text { fibrosis } \\
\text { Mean } \pm \text { SD }\end{array}$ & Median \\
\hline Kontrol vehicle & $0,00^{\mathrm{a}} \pm 0,000$ & 0 \\
Kontrol induksi CCl4 & $3,00^{\mathrm{c}} \pm 0,000$ & 3 \\
Perlakuan 1 (Induksi CCl4+Teripang 75 mg) & $2,00^{\mathrm{b}} \pm 0,577$ & 2 \\
Perlakuan 2 (Induksi CCl4+Teripang 100 mg) & $1,43^{\mathrm{b}} \pm 0,535$ & 1 \\
\hline
\end{tabular}

Keterangan: Superskrip dengan huruf yang berbeda menunjukkan $<0,05$

Hasil yang diperoleh menunjukkan bahwa $100 \%$ tikus pada kelompok kontrol negatif memiliki gambaran hepar yang normal tanpa fibrosis (F0) dan 100\% tikus kelompok kontrol positif ( $\mathrm{CCl} 4$ ) memiliki gambaran fibrosis derajat 3 (F3) atau fibrosis portal dengan banyak septa. Gambaran fibrosis pada kelompok tikus yang diberikan teripang pasir $75 \mathrm{mg} / 200 \mathrm{gBB}$, menunjukkan fibrosis derajat 1, 2, dan 3 masing-masing sebesar $14 \%, 72 \%$, dan $14 \%$. Analisa fibrosis pada kelompok tikus yang diberikan teripang pasir $100 \mathrm{mg} / 200 \mathrm{gBB}$, menunjukkan fibrosis derajat 1 , dan 2 , masing-masing sebesar $57 \%$ dan $43 \%$, serta tidak dijumpai 
fibrosis derajat 3. Uji Kruskal-Wallis menunjukkan perbedaan derajat fibrosis yang signifikan antar keempat kelompok penelitian $(p=0,000)$. Uji post hoc Mannwhitney menunjukkan bahwa derajat fibrosis kelompok kontrol induksi $\mathrm{CCl} 4$ berbeda signifikan dengan kelompok perlakuan yang diberikan teripang pasir 75 dan $100 \mathrm{mg} / 200 \mathrm{gBB}$, namun perbedaan antara kedua kelompok perlakuan tidak signifikan $(p=0,081)$.

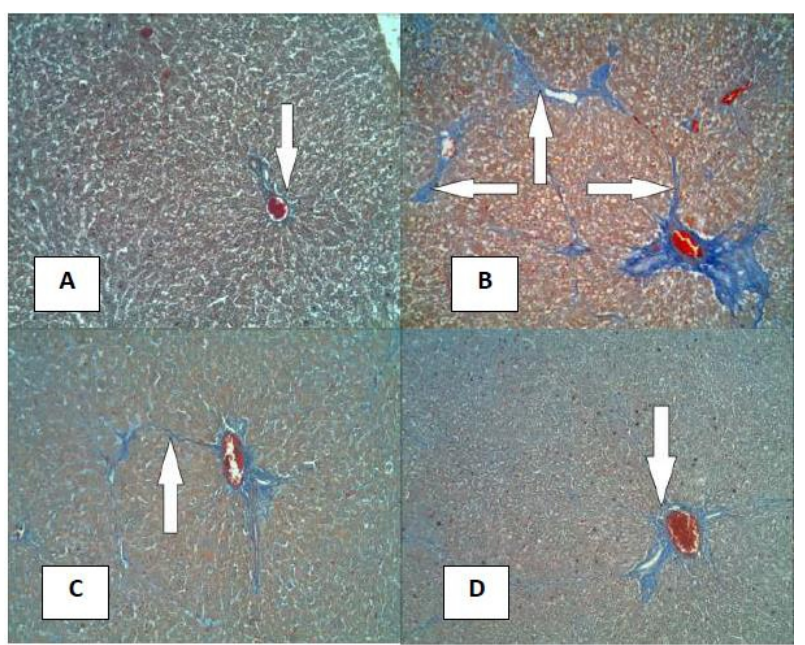

Gambar 1. Gambaran fibrosis jaringan hepar tikus pada keempat kelompok penelitian

Keterangan :

A. dengan pewarnaan Mallory (100x) menunjukkan tidak ada pembesaran traktus portal dan septa pada jaringan hepar tikus kelompok kontrol vehicle (minyak zaitun) (FO)

B. dengan pewarnaan Mallory (100x) menunjukkan fibrosis portal dengan banyak septa atau jaringan fibrosa yang menghubungkan traktus portal (bridging fibrosis) pada jaringan hepar tikus kelompok kontrol CCl4 (CCl4 10\% dalam minyak zaitun) (F3).

C. dengan pewarnaan Mallory (100x) menunjukkan fibrosis portal dengan sedikit septa atau jaringan fibrosa di sekitar traktus portal pada jaringan hepar tikus kelompok perlakuan 1 (induksi $\mathrm{CCl} 4$ dan Teripang pasir $75 \mathrm{mg} / 200 \mathrm{gBB}$ ) (F2)

D. dengan pewarnaan Mallory (100x) menunjukkan fibrosis portal pada jaringan hepar tikus kelompok perlakuan 2 (induksi CCl4 dan Teripang pasir $100 \mathrm{mg} / 200 \mathrm{gBB}$ ) (F1).

\section{DISKUSI}

Fibrosis hepar merupakan akumulasi matriks ekstraseluler sebagai respon terhadap berbagai stimulus dan menyebabkan berbagai kelainan fungsi hepar serta aliran darah. Pada penelitian ini, fibrosis hepar yang terjadi merupakan respon akibat induksi senyawa $\mathrm{CCl} 4$, dimana metabolit senyawa ini, yaitu radikal bebas triklorometil $\left(\mathrm{CCl}_{3}\right)$ dan triklorometilperoksil $\left(\mathrm{CCl}_{3} \mathrm{O}_{2}\right)$, menstimulasi nekrosis sel hepar dan fibrogenesis melalui aktivasi HSC (Hepatic Stem Cell). Analisa derajat fibrosis pada kelompok tikus yang diinduksi $\mathrm{CCl} 4$ (kelompok kontrol positif) memberikan hasil fibrosis pada seluruh sampel tikus. Hasil tersebut sesuai dengan penelitian sebelumnya yang menyatakan bahwa fibrosis dapat dijumpai pada 4 hingga 6 minggu setelah induksi dengan CCl4 0,4-2ml/kgBB sebanyak 2-3 kali dalam seminggu (19).

Fibrosis derajat 3 (F3) yang dijumpai pada semua tikus kelompok kontrol positif, mengindikasikan bahwa kemungkinan bias karena resolusi spontan tidak terjadi, meski analisa dilakukan pada akhir minggu ke-8 atau 3 minggu setelah induksi $\mathrm{CCl} 4$ dihentikan. Hal serupa juga dibuktikan oleh Domitrovic, et al (20). Analisa fibrosis pada seluruh sampel tikus kelompok kontrol positif menunjukkan derajat 3 (F3) atau fibrosis portal dengan banyak septa. Hal serupa juga diamati pada penelitian lain yang menggunakan senyawa $\mathrm{CCl} 4$ selama 4 minggu dan 6 minggu (20-22). Sementara itu, seratus persen tikus pada kelompok kontrol negatif tidak menunjukkan adanya gambaran fibrosis (FO). Hal ini membuktikan bahwa minyak zaitun sebagai pelarut $\mathrm{CCl} 4$ tidak berpengaruh terhadap fibrogenesis.

Uji Kruskal-wallis yang membandingkan frekuensi derajat fibrosis pada keempat kelompok penelitian, menunjukkan adanya perbedaan yang signifikan $(p=0,000)$. Uji Mannwhitney menunjukkan bahwa derajat fibrosis kelompok kontrol induksi $\mathrm{CCl} 4$ berbeda signifikan dengan kelompok perlakuan yang diberikan teripang pasir 75 dan $100 \mathrm{mg} / 200 \mathrm{gBB}$. Hal tersebut membuktikan bahwa ekstrak teripang pasir dapat memperbaiki fibrosis hepar yang diinduksi $\mathrm{CCl} 4$. Mekanisme yang diduga mendasari proses ini adalah aktivitas antioksidan dan antiinflamasi dari senyawa yang terkandung dalam ekstrak teripang pasir. Diantaranya vitamin C, E, polifenol, karotenoid, flavonoid, khondroitin sulfat, DHA dan EPA (9-15). Hal tersebut didukung oleh penelitian Wafa et al, yang menunjukkan bahwa ekstrak teripang pasir memiliki aktivitas antioksidan sedang, yang ditunjukkan dengan kemampuan ekstrak dalam menghambat radikal bebas sebesar $79,82 \%$ (23). Senyawa antioksidan yang terkandung dalam ekstrak teripang pasir diduga menetralkan radikal bebas yang terbentuk dari metabolisme senyawa $\mathrm{CCl} 4$. Akibatnya radikal bebas tidak menstimulasi aktivasi HSC, yang berperan sebagai kunci mekanisme fibrogenesis. Stimulus lain yang dapat mengaktivasi HSC adalah sitokin dan mediator inflamasi yang dilepaskan oleh sel hepar, sel endotel sinusoidal, sel T, sel sel NK (Natural Killer), serta sel Kupffer (24-25). Adanya kandungan senyawa antiinflamasi dalam teripang pasir dapat menghambat respon inflamasi yang bersifat fibrogenik.

Perbedaan derajat fibrosis antara kedua kelompok perlakuan tidak signifikan $(p=0,081)$, namun demikian, frekuensi fibrosis derajat 1 pada kelompok perlakuan 2 yang diberikan teripang pasir $100 \mathrm{mg} / 200 \mathrm{gBB}$, lebih banyak dibandingkan kelompok perlakuan 1 yang diberikan teripang pasir $75 \mathrm{mg} / 200 \mathrm{gBB}$ ( $57 \%$ vs $14 \%$ ). Hasil ini menandakan terjadinya proses regresi pada jaringan hepar yang diinduksi fibrosis, karena tidak dijumpai fibrosis derajat 3 pada tikus kelompok perlakuan 2 setelah pemberian ekstrak teripang pasir selama 4 minggu sejak minggu ke-5 hingga 8.

Hasil penelitian ini membuktikan bahwa pemberian ekstrak teripang pasir dosis $75 \mathrm{mg} / \mathrm{kgBB}$ dan $100 \mathrm{mg} / \mathrm{kgBB}$ dapat memperbaiki fibrosis hepar pada tikus yang diinduksi senyawa $\mathrm{CCl} 4$, dengan aktivitas antifibrotik dosis $100 \mathrm{mg} / \mathrm{kgBB}$ lebih baik dari dosis $75 \mathrm{mg} / \mathrm{kgBB}$. Namun demikian hasil penelitian ini perlu dikonfirmasi dengan parameter lain, diantaranya fungsi hepar (SGOT, SGPT, ALP), indikator stress oksidatif (aktivitas SOD, GSH), sintesis kolagen (kadar hidroksiprolin), aktivasi sel HSC (ekspresi GFAP, $\alpha$-SMA), serta aktivitas degradasi matriks ekstraseluler (konsentrasi MMP dan TIMP).

\section{UCAPAN TERIMAKASIH}

Ucapan terimakasih disampaikan penulis kepada Lembaga Penelitian Universitas Mataram yang telah mendanai 
penelitian ini dari dana DIPA BLU (PNBP) 2015, dan Laboratorium Terpadu FK UNRAM, serta Laboratorium

\section{DAFTAR PUSTAKA}

1. Butt AA, Yan P, Lo RV, et al. Liver Fibrosis Progression in Hepatitis $C$ Virus Infection after Seroconversion. Journal of the American Medical Association Internal Medicine. 2015; 175(2): 178-185.

2. Wong GL, Chan HL, Yu Z, Chan HY, Tse $\mathrm{CH}$, and Wong VW. Liver Fibrosis Progression in Chronic Hepatitis $B$ Patients Positive for Hepatitis $B$ eAntigen: $A$ Prospective Cohort Study with Paired Transient Elastography Examination. Journal of Gastroenterology and Hepatology. 2013; 28(11): 1762-1769.

3. Ponomarenko $\mathrm{Y}$, Leo MA, Kroll W, and Lieber CS. Effects of Alcohol Consumption on Eight Circulating Markers of Liver Fibrosis. Alcohol and Alcoholism. 2002; 37(3): 252-255.

4. Pandit A, Sachdeva T, and Bafna P. Drug-Induced Hepatotoxicity : A Review. Journal of Applied Pharmaceutical Science. 2012; 2(5): 233-243.

5. Angulo $P$, Keach JC, Batts KP, and Lindor KD. Independent Predictors of Liver Fibrosis in Patients with Nonalcoholic Steatohepatitis. Hepatology. 1999; 30(6): 1356-1362.

6. Iredale JP, Benyon RC, Pickering J, et al. Hepatic Stellate Cell Apoptosis and Reduced Hepatic Expression of Metalloproteinase Inhibitors. The Journal of Clinical Investigation. 1998; 102(3): 538-549.

7. Nikolaidis N, Kountouras J, Giouleme $\mathrm{O}$, et al. Colchicine Treatment of Liver Fibrosis. Hepatogastroenterology. 2006; 53(68): 281-285.

8. Ezhilarasan D, Sokal E, Karthikeyan S, and Najimi M. Plant Derived Antioxidants and Antifibrotic Drugs: Past, Present and Future. Journal of Coastal Life Medicine. 2014; 2(9): 738-745.

9. Bordbar S, Anwar F, and Saari N. High-Value Components and Bioactives from Sea Cucumbers for Functional Foods- A Review. Marine Drugs. 2011; 9(10): 1761-1805.

10. Okorie OE, Ko SH, Go S, et al. Preliminary Study of the Optimum Dietary Ascorbic Acid Level in Sea Cucumber, Apostichopus japonicus (Selenka). Journal of the World Aquaculture Society. 2008; 39(6): 758-765.

11. Mamelona J, Pelletier E, Girard-Lalancete K, Legault J, Karboune S, and Kermasha S. Quantification of Phenolic Contents and Antioxidant Capacity of Atlantic Sea Cucumber, Cucumaria frondosa. Food Chemistry. 2007; 104(3): 1040-1047.

12. Althunibat OY, Hashim RB, Taher M, Daud JM, Ikeda $\mathrm{MA}$, and Zali B. In Vitro Antioxidant and Antiproliferative Activities of Three Malaysian Sea Cucumber Species. European Journal of Scientific Research. 2009; 37(3): 376-387.
Patologi Anatomi FK UGM yang telah membantu kegiatan penelitian ini.

13. Ha BJ and Lee JY. The Effect of Chondroitin Sulfate against CCl4-Induced Hepatotoxicity. Biological and Pharmaceutical Bulletin. 2003; 26(5): 622-626.

14. Fredalina BD, Ridwan BH, Abidin AA, et al. Fatty Acid Compositions in Local Sea Cucumber, Stichopus chloronotus, for Wound Healing. General Pharmacology: The Vascular System. 1999; 33(4): 337-340.

15. Wang J, Wang Y, Tang Q, et al. Antioxidant Activities of Low Molecular Weight Gelatin Hydrolysate Isolated from the Sea Cucumber Stichopus japonicus. Journal of Ocean University of China. 2010; 9(1): 94-98.

16. Nurhidayati. Efek Protektif Teripang Pasir (Holothuria scabra) terhadap Hepatotoksistas yang Diinduksi Karbon Tetraklorida (CCl4). [Tesis]. Universitas Airlangga, Surabaya. 2009.

17. Jang JH, Kang KJ, Kim YH, Kang YN and Lee IS. Reevaluation of Experimental Model of Hepatic Fibrosis Induced by Hepatotoxic Drugs: An Easy, Applicable, and Reproducible Model. Transplantation Proceedings. 2008; 40(8): 2700-2703.

18. Bedossa P. Intraobserver \& Interobserver Variations in Liver Biopsy Interpretation in Patients with Chronic Hepatitis C. Hepatology. 1994; 20(1): 15-20.

19. Liedtke $C$, Luedde $T$, Sauerbruch $T$, et al. Experimental Liver Fibrosis Research: Update on Animal Models, Legal Issues and Translational Aspects. Fibrogenesis Tissue Repair. 2013; 6(1): 1-25.

20. Domitrovic R, Jakovac H, Tomac J, and Sain I. Liver Fibrosis in Mice Induced by Carbon Tetrachloride and its Reversion by Luteolin. Toxicology and Applied Pharmacology. 2009; 241(3): 311-321.

21. Lee GP, Jeong WI, Jeong DH, Do SH, Kim TH, and Jeong KS. Diagnostic Evaluation of Carbon Tetrachlorideinduced Rat Hepatic Cirrhosis Model. Anticancer Research. 2005; 25(2A): 1029-1038.

22. Mogler C, Wieland M, Konig C, et al. Hepatic Stellate Cell-Expressed Endosialin Balances Fibrogenesis and Hepatocyte Proliferation during Liver Damage. EMBO Molecular Medicine. 2015; 7(3): 332-338.

23. Wafa JA, Adi TK, Hanapi A, dan Fasya AG Penentuan Kapasitas Antioksidan dan Kandungan Fenolik Total Ekstrak Kasar Teripang pasir (Holothuria scabra) dari Pantai Kenjeran Surabaya. ALCHEMY. 2014; 3(1): 76-83.

24. Bataller R and Brenner DA. Liver Fibrosis. The journal of Clinical Investigation. 2005; 115(2): 209-218.

25. Casini A, Ceni E, Salzano R, et al. Neutrophil-Derived Superoxide Anion Induces Lipid Peroxidation and Stimulates Collagen Synthesis in Human Hepatic Stellate Cells: Role of Nitric Oxide. Hepatology. 1997; 25(2): 361-367. 